\title{
ANALISIS KESALAHAN EJAAN DAN PILIHAN KATA PADA SURAT DINAS DI STKIP AL HIKMAH SURABAYA
}

\author{
Ady Dwi Achmad Prasetya \\ STKIP Al Hikmah Surabaya \\ adydapcivil@gmail.com
}

ABSTRAK

ABSTRACT

PENDAHULUAN
Penelitian ini bertujuan mendeskripsikan kesalahan ejaan dan pilihan kata pada surat dinas di STKIP Al Hikmah Surabaya. Data penelitian adalah surat dinas yang dibuat oleh sekretaris STKIP Al Hikmah, Prodi Pendidikan Matematika, Prodi Pendidikan Bahasa Inggris, Prodi Pendidikan Fisika, Prodi Pendidikan Bahasa Indonesia, dan Prodi Pendidikan Guru Sekolah Dasar. Metode penelitian ini adalah deskriptif kualitatif. Teknik pengambilan data yang digunakan dalam penelitian ini adalah purposive sampling. Data dikumpulkan dengan cara mengkaji dokumen atau arsip dengan menggunakan teknik analis dokumen. Hasil penelitian ini menunjukkan adanya kesalahan dalam penulisan surat dinas di STKIP Al Hikmah Surabaya, yaitu kesalahan ejaan berupa penggunaan huruf kapital, tanda koma, tanda titik dua, dan pilihan kata.

Kata Kunci: kesalahan ejaan, pilihan kata, surat dinas

This research aims to describe the orthographic and word choice error in official letter at STKIP Al Hikmah Surabaya. The research data of this research is the official letter written by the secretary of STKIP Al Hikmah, Mathematics education department, English education department, Physics education department, Bahasa education department, and Early school education department. The research methodology applied in this research was qualitative descriptive method. The data collection technique used in this research was purposive sampling. The data were collected by analyzing the documents or archives using document analysis technique. The result of this research shows that there are some orthographic and word choice errors occurred in the official letter at STKIP Al Hikmah Surabaya such as capitalization, comma, colon, and word choice.

Keywords: orthographic error, word choice, official letter

Komunikasi diperlukan oleh setiap makhluk sosial untuk berinteraksi dengan orang lain. Bahasa merupakan media berkomunikasi untuk menyampaikan pesan atau informasi, baik secara lisan maupun tulis. Tanpa adanya bahasa, komunikasi menjadi terhambat. Pengiriman pesan membutuhkan bahasa sebagai media komunikasi antara pengirim pesan dengan penerima pesan.

Salah satu media komunikasi yang berbentuk tulisan adalah surat. Menurut Semi (2008:1) bahwa surat adalah sarana untuk 
menyampaikan informasi secara tertulis dari pihak yang satu ke pihak yang lain. Informasi itu dapat berupa pemberitahuan, pernyataan, pertanyaan, permintaan, sikap, dan lain. Dengan kata lain, surat merupakan media komunikasi yang berbentuk tulisan yang digunakan untuk berbagai keperluan manusia.

Penggunaan surat sebagai media komunikasi memiliki banyak kelebihan. Menurut Arifin (1987:12) bahwa kelebihan surat dibandingkan dengan alat komunikasi lisan, yaitu dapat mengurangi kesalahpahaman dalam berkomunikasi karena penulis dapat menyampaikan maksudnya dengan sejelas-jelasnya. Selain itu, kelebihan surat yang lainnya adalah praktis, efektif, dan ekonomis. Menurut Setyoningrum (2008: 1-2) bahwa kegiatan suratmenyurat masih tetap dilaksanakan meskipun teknologi semakin canggih. Dalam perkembangan teknologi di bidang elektronik, pesan dapat disampaian dengan menggunakan telepon genggam, facebook, BBM, dan lain-lain.

Berdasarkan isinya, surat dapat dibedakan menjadi tiga jenis, yaitu surat pribadi, surat dinas/resmi, dan surat dagang/niaga. Menurut Soedjito \& Solchan (2001:14) bahwa surat dinas/resmi adalah surat yang berisi masalah kedinasan atau administrasi pemerintahan. Karena sifatnya resmi, surat resmi harus ditulis menggunakan bahasa ragam resmi). Bahasa ragam resmi yang dimaksud adalah bahasa Indonesia yang baik dan benar.

Salah satu instansi yang menggunakan surat sebagai alat komunikasi adalah perguruan tinggi. Seperti yang telah kita ketahui, dalam suatu instansi, khususnya perguruan tinggi banyak melaksankan kegiatan yang melibatkan banyak pihak. Oleh karena itu, untuk memperlancar pelaksanaan kegiatan tersebut, diperlukan media komunikasi berupa surat untuk menyampaikan informasi seperti surat tugas, pemberitahuan, undangan, permintaan, maupun teguran kepada pihak-pihak yang bersangkutan.

Surat-surat yang dikeluarkan oleh perguruan tinggi sudah seharusnya menggunakan bahasa dan tata cara penulisan yang baku sebagaimana yang tertulis dalam pasal 33 ayat 1 Undang-Undang Nomor 24 Tahun 2009 yang berbunyi "Bahasa Indonesia wajib digunakan dalam komunikasi resmi di lingkungan kerja pemerintah dan swasta”. Komunikasi yang dimaksud adalah komunikasi resmi di komunikasi jarak dekat maupun jarak jauh. Penggunaan bahasa yang baku dan tata cara penulisan yang baku akan mempermudah pemahaman pesan yang disampaikan serta akan mengurangi risiko salah penafsiran. Dengan demikian, kegiatan komunikasi akan berjalan lancar. Menurut Yulianto (2007: 20) bahwa menulis surat bukan hanya sekedar menyampaikan pesan kepada orang lain, tetapi juga memerlukan keterampilan khusus.

Berdasarkan pengamatan awal, surat dinas yang dikeluarkan oleh STKIP Al Hikmah Surabaya masih terdapat kesalahan, baik dari segi ejaan maupun pemilihan kata. Ketidaktepatan penulisan surat dinas akan menjadikan informasi surat sulit dipahami. Menurut Hastuti (dalam Darmasuti, 2009) bahwa surat yang kurang jelas maksudnya akan mengakibatkan berbagai hal yang negatif, di 
antaranya: (1) penerima surat tidak bisa memahami isinya; (2) jawaban yang dikehendaki oleh si penerima surat tidak seperti yang dikehendaki oleh si pengirim surat; dan (3) isi surat akan meragukan penerima surat. Oleh karena itu, hal-hal seperti yang telah disebutkan di atas harus dihindari guna memperlancar komunikasi sehingga kegiatan yang telah direncanakan dapat terlaksana dengan baik. Masalah yang akan dibahas dalam penelitian ini adalah bagaimana kesalahan ejaan dan pilihan kata pada surat dinas di STKIP Al Hikmah Surabaya.

Menurut Sriyanto (2016:18 - 30) kalimat yang baik merupakan kalimat yang taat terhadap asas atau mengikuti kaidah yang berlaku. Berikut kaidah penulisan huruf kapital: (1) huruf kapital dipakai sebagai huruf pertama awal kalimat; (2) huruf kapital dipakai sebagai huruf pertama petikan langsung; (3) huruf kapital dipakai sebagai huruf pertama dalam ungkapan-ungkapan yang berhubungan dengan keagamaan, kitab suci, nama Tuhan termasuk kata ganti; (4) huruf kapital dipakai sebagai huruf pertama gelar kehormatan, keturunan, dan keagamaan yang diikuti nama orang; (5) huruf kapital dipakai sebagai huruf pertama nama jabatan dan pangkat yang diikuti nama orang; (6) huruf kapital dipakai sebagai huruf pertama nama orang; (7) huruf kapital dipakai sebagai huruf pertama nama agama, bangsa, dan suku; (8) huruf kapital dipakai sebagai huruf pertama nama hari, bulan, tahun, peristiwa sejarah, dan hari raya; (9) huruf kapital dipakai sebagai huruf pertama nama geografi; (10) huruf kapital dipakai sebagai huruf pertama nama resmi badan, lembaga pemerintahan dan ketatanegaraan, serta nama dokumen resmi; (11) huruf kapital dipakai sebagai huruf pertama semua kata untuk nama buku, majalah, surat kabar, dan judul karangan; (12) huruf kapital dipakai sebagai singkatan nama, gelar, dan sapaan; (13) huruf kapital dipakai sebagai huruf pertama kata penunjuk hubungan keakraban seperti bapak, ibu, kakak, saudara, dan paman yang dipakai sebagai kata ganti atau sapaan.

Pemakaian tanda koma sudah diatur dalam pedoman ejaan bahasa Indonesia. Dalam Panitia pengembangan Bahasa Indonesia (2016:39-44) menjelaskan bahwa penggunaan tanda koma digunakan untuk penulisan gelar akademik dan kalimat majemuk. Penulisan tanda koma pada gelar akademik ditulis diantara nama dan singkatan gelar yang mengikutinya. Penulisan tanda koma pada kalimat pajemukdigunakan untuk memisahkan anak kalimat dari induk kalimat jika anak kalimat mendahului induknya.

Menurut Jumariam, et al (2001:39—41) bahwa tanda titik dua dipakai pada akhir pernyataan lengkap jika diikuti rangkaian atau pemerian. Kalimat tersebut menyatakan penggunaan tanda titik dua tidak harus digunakan. Pernyataan tersebut sekurang-kurangnya harus mengandung unsur subjek dan predikat. Rangkaian atau pemerian merupakan rincian penguraian unsur-unsurnya. Tanda titik dua digunakan sesudah pernyataan yang diikuti perincian yang merupakan bagian dari pernyataan lengkap.

Menurut Mustakim (2016:49-74) bahwa penggunaan bentuk dan pilihan kata harus memenuhi kriteria ketepatan, kecermatan, 
dan keserasian. (1) Ketepatan pemilihan kata berkaitan dengan kemampuan memilih kata yang digunakan mengungkapkan gagasan secara tepatdan dapat diterima pembaca atau pendengar. Ketepatan dalam pemilihan kata dapat dicapai jika pemakai bahasa memahami penggunaan kata dengan makna denotatif dan konotatif, sinonim, eufimisme, generik dan special, serta konkret dan abstrak. (2) Kecermatan pemilihan kata berkaitan dengan penggunaan kata untuk menhindari kemubaziran penggunaan kata. Kalau ada kata atau ungkapan lebih singkat tidak perlu menggunakan kata atau ungkapan yang panjang. (3) Keserasian dalam pemilihan kata berkaitan dengan kemampua menggunakan kata-kata yang sesuai dengan konteks, yaitu factor kebahasaan dan nonkebahasaan. Faktor kebahasaan dalam keserasian pilihan kata antara lain penggunaan kata yang sesuai dengan konteks kalimat, bentuk gramatika, idiom, majas, dan kata lazim.

METODE

\section{PEMBAHASAN}

Penelitian ini menggunakan metode deskriptif kualitatif. Data penelitian yang digunakan adalah surat dinas yang dibuat oleh sekretaris STKIP Al Hikmah, sekretaris Prodi Pendidikan Matematika, sekretaris Prodi Pendidikan Bahasa Inggris, Prodi Pendidikan Fisika, Prodi Pendidikan Bahasa Indonesia, dan Prodi Pendidikan Guru Sekolah Dasar. Teknik pengambilan data yang digunakan dalam penelitian ini adalah purposive sampling. Data dikumpulkan dengan cara mengkaji dokumen atau arsip dengan menggunakan teknik analis dokumen.

\section{Ketidaktepatan Pemakaian Ejaan}

\section{Pemakaian Huruf Kapital}

Berdasarkan data penelitian yang diperoleh, peneliti menemukan ketidaktepatan pemakaian huruf capital dengan kaidah pedoman ejaan bahasa Indonesia. Data tersebut dapat dilihat pada sebagian kalimat yang terdapat pada surat dinas yang dibuat sekretaris STKIP Al Hikmah Surabaya. Berikut data-data contoh ketidaktepatan penggunaan huruf kapital.

(1) Sebagai bagian dari Evaluasi Mahasiswa selama studi di Kampus STKIP Al Hikmah.

$(12 / \mathrm{SD} / 2019)$

(2) Bersama dengan surat yang ketiga kalinya ini, kami mengharap dengan hormat kesediaan Bapak dan Ibu untuk hadir, pada:

$\begin{array}{ll}\text { Hari / Tanggal } & \text { : Rabu, 06 Desember } 2018 \\ \text { Waktu } & \text { : Pukul 13.00 WIB } \\ \text { Tempat } & \text { : Kantor STKIP Al Hikmah } \\ & \text { Gedung Barat Lt. } 3 \\ & \text { Jl. Kebonsari Elveka V Surabaya } \\ \text { Agenda } & : \begin{array}{l}\text { Penyampaian hasil evaluasi belajar } \\ \text { mahasiswa }\end{array}\end{array}$

$(12 / \mathrm{SD} / 2018)$ 
(3) Adapun agendanya adalah sebagai berikut:

Hari, Tanggal : Kamis, 10 Januari 2019

Waktu : Pukul $09.00-11.00$ WIB

Tempat : Ruang Arofah, Lt. 4 Kampus STKIP Al Hikmah

Jl. Kebonsari Elveka V Surabaya

Materi : Perjalanan Menjadi Guru SD

Peserta $\quad$ : Mahasiswa dan dosen STKIP AL Hikmah

(13/SD/2019)

(4) Dalam rangka meningkatkan kualitas pembelajaran, Prodi S1 Pendidikan Matematika akan menyelenggarakan Kuliah Umum dengan topic Lesson Study for Learning Community Pendidikan Matematika Realisasi Indonesia yang disampaikan oleh Prof Dr. Ratu Ilma Indra Putri dari Universitas Sriwijaya.

$$
\begin{array}{ll}
\text { Hari/Tanggal } & : \text { Kamis/ } 12 \text { April } 2018 \\
\text { Waktu } & : 08.00-09.00 \text { WIB } \\
\text { Tempat } & : \text { R. Arofah }
\end{array}
$$

Pada contoh data (1) penulisan evaluasi mahasiswa pada kalimat ... Evaluasi Mahasiswa selama studi di Kampus STKIP Al Hikmah kurang tepat. Penulisan huruf capital digunakan untuk menuliskan huruf pertama pada nama hari, bulan, tahun, dan hari raya. Jadi penulisan kata evaluasi mahasiswa seharusnya diawali dengan huruf kecil. Penulisan data (1) yang benar adalah evaluasi mahasiswa selama studi di Kampus STKIP Al Hikmah.

Data (2) menunjukkan ketidaktepatan penulisan menggunakan huruf kapital. Penulisan hari, tanggal, waktu, tempat, agenda tidak perlu diawali menggunakan huruf kapital karena masih dalam satu rangkaian kalimat sebelumnya. Penulisan kata jalan tidak disingkat dengan $J l$. tetapi Jln. atau ditulis lengkap jalan.

Penulisan hari, tanggal, waktu, tempat, materi, peserta pada data (3) tidak perlu diawali menggunakan huruf kapital karena masih dalam satu rangkaian kalimat sebelumnya. Penulisan kata sampai tidak ditulis dengan tanda hubung (-) tetapi ditulis dengan dua tanda hubung (--), atau tanda pisah (-). Jadi perbaikan pada data (3) adalah 09.00--11.00 WIB, atau 09.00-11.00 WIB.

Contoh data (4) terdapat penulisan huruf kapital yang kurang tepat. Penulisan hari, tanggal, waktu, tepat tidak perlu diawali menggunakan huruf kapital karena masih dalam satu rangkaian kalimat sebelumnya. Penulisan S1 pada data (4) yang tepat adalah $S-1$. Penulisan kata sampai tidak ditulis dengan tanda hubung (-) tetapi ditulis dengan dua tanda hubung (--), atau tanda pisah (-).

Selain contoh data di atas, penulisan huruh capital yang tidak tepat dengan kaidah bahasa Indonesia dapat dilihat pada contoh berikut. 
(5) Kepada Yth.

Dekan FIP UNESA

Drs. Sujarwanto, M.Pd.

di Tempat

Assalamu’alaikum, Wr. Wb.

Alhamdulillahirabbil 'alamin assholatu wassalamu 'ala Rasulillah Muhammad SAW.

Dalam rangka meningkatkan kualitas pembelajaran mahasiswa, Prodi S1 Pendidikan Guru Sekolah Dasar mengundang Ibu Neni Mariana, S.Pd., M.Sc., Ph.D. untuk menjadi narasumber pada kuliah tamu yang akan dilaksanakan pada:

hari/tanggal : Sabtu/ 9 Desember 2017

waktu : $10.00-14.05$ WIB

tempat : Kampus STKIP Al Hikmah Lantai $4 \mathrm{R}$. Arofah

peserta : Mahasiswa Angkatan 2017

Demikian surat undangan ini kami sampaikan. Atas perhatian dan kerjasamanya, kami ucapkan terimakasih.

Wassalamu'alaikum, Wr. Wb.

Pada contoh data (5) ditemukan kesalahan ejaan bahasa Indonesia. Penulisan kata Kampus dan Mahasiwa tidak perlu diawali dengan huruf capital. Penulisan yang benar adalah kampus dan mahasiswa. Selain kata tersebut, penulisan Dekan FIP UNESA, Drs. Sujarwanto, M.Pd., Ibu Neni Mariana, S.Pd., M.Sc., Ph.D. tidak perlu ditebalkan. Penulisan kalimat yang benar adalah Dekan FIP UNESA, Drs. Sujarwanto, M.Pd., Ibu Neni Mariana, S.Pd., M.Sc., Ph.D.

Penulisan yang benar pada data (5) adalah sebagai berikut.

(5) Yth.

Dekan FIP UNESA

Drs. Sujarwanto, M.Pd.

Di Tempat

Assalamualaikum W. W.,

Alhamdulillahirabbil 'alamin assholatu wassalamu 'ala Rasulillah Muhammad Saw.

Dalam rangka meningkatkan kualitas pembelajaran mahasiswa, Prodi S-1 Pendidikan Guru Sekolah Dasar mengundang Ibu Neni Mariana, S.Pd., M.Sc., Ph.D. untuk menjadi narasumber pada kuliah tamu yang akan dilaksanakan pada

$$
\begin{array}{lll}
\text { hari/tanggal } & : & \text { Sabtu, } 9 \text { Desember } 2017 \\
\text { waktu } & : & 10.00--14.05 \text { WIB } \\
\text { tempat } & : & \text { ruang arofah lantai } 4 \text {, kampus STKIP Al } \\
& \text { Hikmah } \\
\text { peserta } & : \text { mahasiswa angkatan } 2017
\end{array}
$$

Demikian surat undangan ini kami sampaikan. Atas perhatian dan kerjasamanya, kami ucapkan terimakasih.

Wassalamualaikum W. W. 


\section{Penggunaan Tanda Koma (,)}

Peneliti menemukan beberapa ketidaktepatan dalam penggunaan tanda koma. Berikut data ketidaktepatan dalam penggunaan tada koma.

(6) Kepada Yth, Kaprodi Pendidikan Bahasa Indonesia

Di Tempat

(7) Kepada Yth,

Ibu Romlah, S.Pd., M.Pd.Gr

Guru SDN Ombul 1 Kedungdung

Sampang

(13/SD/2019)

Pada contoh data (6) dan (7) terdapat kesalahan penggunaan tanda baca yang tidak tepat. Penulisan Yth, yang tepat adalah menggunakan tada titik. Perbaikan penulisannya adalah Yth.

\section{Penggunaan Tanda Titik Dua (:)}

Sesuai data surat dinas di STKIP Al Hikmah Surabaya, peneliti menemukan ketidaktepatan penggunaan tanda baca titik dua. Berikut contoh penggunaan tanda baca titik dua yang tidak tepat.

(8) Adapun agendanya adalah sebagai berikut:

$(13 / \mathrm{SD} / 2019)$

(9) Dalam rangka meningkatkan ukhuwah Islamiyah Civitas Akademika Prodi S1 Pendidikan Matematika, kami mengundang ustadz Moch. Ikhsan, S.Pd.I. untuk hadir dalam Acara Buka Puasa Bersama yang akan dilaksanakan pada:

$(15 / \mathrm{SD} / 2018)$

Kegunaan tanda baca titik dua adalah untuk mengakhiri pernyataan lengkap jika diikuti rangkaian atau pemerian. Penggunaan tanda baca titik dua pada data (8) dan (9) adalah kurang tepat karena kalimat tersebut bukan bukan sebagai pernyataan yang lengkap. Penulisan yang benar adalah sebagai berikut.

(8) Adapun agendanya adalah sebagai berikut...

(9) Dalam rangka meningkatkan ukhuwah Islamiyah Civitas Akademika Prodi S-1 Pendidikan Matematika, kami mengundang ustaz Moch. Ikhsan, S.Pd.I. untuk hadir dalam Acara Buka Puasa Bersama yang akan dilaksanakan pada...

\section{Pemilihan Kata yang Tidak Tepat}

Dari data yang diperoleh, peneliti menemukan ketidaktepatan dalam pemilihan kata. Berikut contoh data ketidaktepatan dalam pemilihan kata.

(10) Kepada Yth.

Ust. Ady Dwi Achmad Prasetya, M.Pd.

Anggota Senat STKIP Al Hikmah Surabaya

di Tempat

$(17 / \mathrm{SD} / 2018)$ 
(11) Bersama ini, kami atas nama STKIP Al Hikmah Surabaya menyampaikan terima kasih yang sebesar-besarnya kepada Ibu Romlah, S.Pd., M.Pd.Gr. yang telah hadir sebagai pembicara Kuliah Umum Guru Inspiratif pada tanggal 10 Januari 2019

$(11 / \mathrm{SD} / 2019)$

\section{SIMPULAN}

Berdasarkan data yang diperoleh dari surat dinas di STKIP Al Hikmah Surabaya, peneliti menemukan beberapa kesalahan dalam penulisan surat dinas. Hasil analisis, peneliti dapat mengambil simpulan sebagai berikut.

1. Penulisan surat dinas ditemukan penggunaan ejaan yang tidak sesui dengan kaidah bahasa Indonesia yang baik dan benar. Ketidaksesuaian tersebut meliputi, penggunaan huruf kapital, tanda koma, dan titik dua.

2. Kesalahan penulisan juga terdapat dalam pemilihan kata sehingga makna yang terkandung dalam kalimat di dalam surat dinas berbeda dengan makna yang sebenarnya.

\section{DAFTAR PUSTAKA}

Arifin, Zaenal. 1987. Penggunaan Bahasa Indonesia dalam Surat Dinas. Jakarta: PT. Mediyatama Sarana Perkasa.

Darmasuti, Feri Defita. 2009. Analisis Kesalahan Berbahasa dalam Surat Dinas Kantor Kelurahan Ngolodono Karangdowo Klaten. Skripsi tidak dipublikasikan, FKIP Universitas Muhammadiyah Surakarta, Surakarta.

Jumariam. Et al. 2001. Ejaan Bahasa Indonesia: Bahan Penyuluhan. Jakarta: Pusat Bahasa. Departemen Pendidikan Nasional.

Mustakim, 2016. Bentuk dan Pilihan Kata. Jakarta: Pusat Pembinaan. Badan Pengembangan dan Pembinaan Bahasa. Kementrian Pendidikan dan Kebudayaan.
Panitia Pengembangan Pedoman Bahasa Indonesia. 2016. Pedoman Umum Ejaan Bahasa Indonesia. Jakarta. Badan Pengembangan dan Pembinaan Bahasa. Kementrian Pendidikan dan Kebudayaan.

Semi, Atar. 2008. Terampil Menulis Surat. Bandung: Titian Ilmu.

Setyoningrum, Afra Tien. 2008. Korespondensi bahasa Indonesia. Yogyakarta: Amara Books.

Soedjito \& Solchan. 2001. Surat Menyurat Resmi Bahasa Indonesia. Bandung: PT. Remaja Rosdakarya.

UU RI. 2009. Undang-Undang Republik Indonesia Nomor 24 Tahun 2009 Tentang Bendera, Bahasa, dan Lambang Negara, serta Lagu Kebangsaan. Jakarta.

Yulianto, Bambang. 2007. Mengembangkan Menulis Teknis. Surabaya: Unesa University Press. 